\title{
The Philippine-US Relations: Living or Leaving the Bandung Spirit?
}

\author{
Anna Rhodora Solar \& John Matthew Poblete \\ De La Salle-College of Saint Benilde
}

\begin{abstract}
The Philippines had its own share of colonial past. Just as other Asian and African countries which were under the Western colonizers, the Philippines partook of the momentous event that proposed an alternative to the world order dominated by superpowers-the Bandung Conference. The principles collectively known as Bandung Spirit were embraced by the Philippines and had a clear understanding of its symbolic significance. Yet such understanding of these principles was coupled with compromises on the Philippines relations with the United States. Over the decades, the Philippines had to do a balancing act between its being sovereign, independent state and its recognition of the relevance of its past colonial master-the US. Hence, this raises the question of whether the Philippines is living or leaving the Bandung Spirit. Specifically, this paper assesses whether the Philippines still upholds the same Bandung Spirit in its traditional form or has it given a contemporary understanding of it. The paper argues that the Philippine-US relations remain to be an evident display of US presence in Southeast Asia albeit redefined to blend with the Bandung Spirit.
\end{abstract}

Keywords: Bandung Conference, Bandung spirit, Philippine foreign policy, the Philippines-US relations, bilateralism, anti-Colonialism, political independence, economic development

\begin{abstract}
Abstrak
Filipina memiliki bagiannya tersendiri pada masa colonial. Sama seperti negara-negara Asia dan Afrika lainnya yang berada di bawah koloni Barat, Filipina mengambil bagian dalam peristiwa sangat penting yang memberikan alternatif pada tatanan dunia yang didominasi oleh kekuatan super-Konferensi Bandung. Prinsip-prinsip kolektif yang dikenal sebagai Semangat Bandung dianut oleh Filipina dan dipahami signifikansi simboliknya. Namun pemahaman prinsip-prinsip inijuga dibarengi dengan kompromi hubungan Filipina dengan Amerika Serikat. Selama beberapa dekade, Filipina harus melakukan aksi penyeimbang antara dirinya yang merdeka, negara independen dan dirinya yang mengakui relevansi penjajah masa lalunya-AS. Oleh karenanya, hal ini memunculkan pertanyaan apakah Filipina sedang hidup dengan cara Semangat Bandung atau meninggalkan Semangat Bandung. Secara spesifik, tulisan ini mengaji apakah Filipina masih menjunjung Semangat Bandung yang sama dengan bentuk tradisionalnya ataukah ia telah memberikan pemahaman kontemporer atas Semangat Bandung ini. Tulisan ini memiliki argumen bahwa hubungan Filipina-AS masih menjadi bukti kuat keberadaan AS di Asia Tenggara meski telah didefinisikan ulang untuk bercampur dengan Semangat Bandung.
\end{abstract}

Kata Kunci:_Konferensi Bandung, semangat Bandung, kebijakan luar negeri Filipina, hubungan FilipinaAS, bilateralisme, anti-kolonialisme, kemerdekaan politik, pembangunan ekonomi. 


\section{Introduction}

The Bandung Spirit takes its name from the Bandung Conference, formally known as the Asian-African Conference, which was held in the town of Bandung, Indonesia in 1955. The conference reflected the dissatisfaction of governments such as Indonesia, Burma (Myanmar), Ceylon (Sri Lanka), India and Pakistan on the slow pace of decolonization in the early 1950s. It was an opportunity for countries to express their opposition to colonialism (Berger, 2004, p. 48).

The final communique of the conference condemned all manifestations of colonialism. The proceeding ended with a call for increased technical and cultural cooperation among governments in attendance; the establishment of an economic development fund to be operated by the United Nations; increased support for human rights and the self-determination of people and nations; and negotiations to reduce the building and stockpiling of nuclear weapons (Abdulgani, 1964, p. 98-101).

To this day, the spirit of Asian-African solidarity remains. Although there is no common cultural heritage among Asia and African nations, they have certain attitude in common, that is abhorrence to colonialism and imperialism; and determination to keep at all times mutual respect, mutual understanding, and mutual benefit among themselves (Abdulgani, 1963). This single force that binds them is known as the Bandung Spirit.

Each nation, however, had its own interpretation and its own reading of the implication of the Bandung Spirit. This paper therefore, analyses the Bandung Spirit in light of the Philippines' definition of its national individuality through the formulation of its foreign policy over time. Specifically, the paper answers the question of whether the Philippines is living or leaving the Bandung Spirit. To address this, the paper is divided in two major parts. The first part assesses the foreign policy formulation of the Philippines since the Bandung Conference and argues that such process has involved balancing act between national interest and the relevance the United States as former colonizer. The second part argues that the Bandung Spirit was adapted by the Philippines in its attempt to address its national interests while keeping its commitment to the ideals of the Bandung Conference.

\section{The Bandung Spirit: Redefining the Colonizer-Colony Relations}

The Bandung Spirit embodies core principles which include anti-colonialism, political freedom and state-guided economic development. Externally, it safeguards state from possible interference of hegemonic country. Internally, it allows state to steer its development free from external pressure. Hence, it reflects both external and internal environment by which state defines its national individuality.

The creation of foreign policy is an assertion of national individuality. It provides former colony full control of its internal affairs while providing safeguard from possible interference of former colonial master. In effect, it redefines the relationship between the former colonizer and its colony resulting to equal partnership instead of predomination. This section assesses the extent to which Philippine foreign policy is consistent with the Bandung Spirit. It argues that Philippine foreign policy remains broadly infused with the Bandung Spirit while remains to be engaged with its former colonizer-the US.

\section{Conceptual Framework: The Dual Actor Model}

Figure 1 The Dual Actor Model

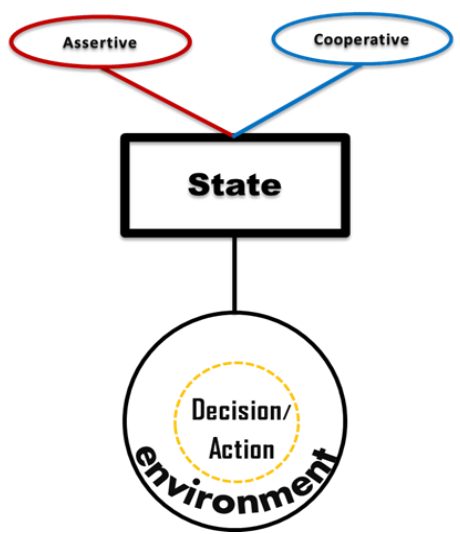

The Dual Actor Model asserts that the state has a tendency to play both an assertive and a cooperative role as these are inherent features of a state. This becomes reflective on the 
decision pursued by the state. Such decision, however, is conditioned by both domestic and international security environment which necessitates the state to perform a balancing act. The Philippines as a dual actor has a tendency to assert its national interest and cooperate with its former colonial master-the US. Although this may send an impression on the ambiguity of the Philippines commitment to the Bandung Spirit-anti-colonialism, political freedom, and state-guided economic development-it should be perceived that such balancing act is a means by which the state adjusts or adapts to the evolving environment while preserving its national individuality.

\section{The Balancing Act: Philippine National Interest and American Influence}

The Philippine-US relations highlight a shared history based on the latter's colonization of the archipelago from 1889-1946. Today, the two countries continue to be linked by their security concerns, democratic principles, and economic ties. Yet the road to their evergrowing cordial relations is beset with challenges particularly in the attempt of the Philippines to define its national individuality through the creation of its independent foreign policy. This necessitated the Philippines to perform a balancing act in the international stage. In light of this, the paper centers on two major points of discussion which explain the balancing act. The first focuses on the politicosecurity concerns while the other on economic issues.

\section{Politico-Security Concerns}

The Philippine-US relations in the 1930 s to 1950 s can be best described as the era of the "achievement of Philippine Independence". It was during this decade that Philippine was advancing to its independence. Yet before it reached that point, the US offered a number of treaties albeit with certain conditions. One such case is the passage of the 1933 HareHawes Cutting Act in the US Congress which was eventually turned down by the Philippine Legislature under Senate President Manuel Quezon, primarily because it gave the US President a two-year unilateral authority of retaining military bases in the Philippines. The reservation of military bases in the Philippines would in effect nullify its independence. The US having understood the Philippine sentiments, revised and offered another treaty called the "1934 Tydings-Mcduffie Act", more or less identical to the earlier independence act except that it stated that the United States would have no military bases in the Philippines after independence (Shalom n.d., p. 2-4). However, the naval reservations held by the US would be retained until negotiations between Washington and Manila within two years of independence settled all questions related to such facilities. The Tydings-McDuffie Act did not offer the Philippines the "real and complete" independence that Quezon claimed for, given that the failure of post-independence negotiations to reach agreement on naval bases would leave the United States in possession of any naval reservations previously retained. Nevertheless, the Philippine legislature accepted the act, and a Philippine commonwealth was soon inaugurated, with Quezon as its President and independence scheduled to follow a decade (Shalom, 2012).

As the 10-year period reached its end in 1944, negotiations began to start with regards to U.S naval bases. Although the Philippines was previously against the retention of military bases, President Quezon and Vice President Osmeña became open to the idea. They realized that the Philippinesalthough soon to be independent-remained susceptible to any foreign attacks, and that a US presence of military bases would, to a certain extent, give them a boosted confidence with regards to their national security. Eventually, the Philippines gained its independence through "The Treaty of Manila in 1946" under the Philippine Presidency of Manuel Roxas (1946-1948). Under this agreement, it involved the assurance of further maintained U.S Military bases, hence, the Military Bases Agreement (MBA) of 1946.The series of events that led to the Philippine independence is a notable response of the US to the concerns of the Philippines and its willingness to give its independence. On the other hand, it also indicated the Philippines assertion of its own independence (Communist Party of the Philippines, 2011).

After gaining its independence, the Philippines signed under the presidency of 
Elpidio Quirino (1948-53) another agreement with the US. The signing of the "Mutual Defense Pact of 1951" was aimed to further strengthen the relations of the Philippines and the US (Malaya, 2011, p. 1). The agreement became the overall framework for the USPhilippine mutual defense in the event of foreign attacks on metropolitan territories, armed forces, public vessels, or aircraft of either country. It was a vital link in the US line of defense in the Western Pacific. The contracting countries agreed to maintain and develop their individual and collective capacity to resist attacks. This was put to the test during the administration of President Ramon Magsaysay (1953-1957) as he turned to the U.S to resolve the insurgency groups-known as "Hukbalahap" or "huks"-spreading in the Philippines. The US gladly helped in warding off the Huks and was successfully finished in 1954. Such was a display of good Philippine-US relations. However, the discussion on the renewal of military bases in the Philippines failed in 1956. This was mainly because of the American soldiers accused of violating Philippine laws. The US had generally refused to turn such individuals over to the Philippine justice system, which infuriated many Filipinos. Thus, the talks were unsuccessful (Stephens, 1990, p. 26).

Over the years, the Philippines and the US underwent several negotiations with regard to the US military presence in the Philippines. For instance, in the 1959 Bohlen-Serrano Agreement which was signed under President Carlos P. Garcia (1957-1961), the Philippine asserted to shorten the length of US military bases from 99 years to 25 years (UN Treaty Series n.d., p. 306). On the other hand, the U.S. agreed not to station nuclear missiles, to turn over unused bases, to consult before launching combat operations, and to turn over to the Philippine administration the Subic Bay town of Olongapo which at that time was under US jurisdiction. In return, the Philippines allowed the US to enlarge the Subic Bay and Sangley Point Naval Stations. However, during President Diosdado Macapagal (1961-1965), the issue of jurisdiction (legal control) over American soldiers in the Philippines, which had not been fully settled after the 1959 discussions, continued to be a problem. It was only during the reign of President Ferdinand Marcos (1965-1986), that this issue was resolved through the formation of a "Joint Jurisdictional Implementation Committee" (a result of the 1965 talks) and a mutual agreement, on both sides, to give sympathetic consideration to waive jurisdiction in those cases of a "particular national interest" (Cooley, 2008, p. 69).

The above-mentioned events reflected the attempt of the Philippines to address its national interest by retaining the US involvement to a certain degree but not to the extent of sacrificing its own sovereignty. The Philippines strategically made use of its strong relations with the US in order to resolve a problem of its own. The domestic insurgency was key determinant to the decisions made by the Philippines. However, it was not the sole determinant. The Philippines, being a newlyindependent sovereign nation-state, was also sensitive to any breach towards its Constitution. This showed an evidence of the Philippines assertion of its sovereignty as it did not easily succumb to the idea of discussing new bases agreement simply because the US did help them fend off the Huks. Instead, the Philippines displayed its strong national individuality. In response, the US, although rejected the idea of bringing its soldiers before the Philippine court, did not insist nor persuade the Philippines but rather accepted the failure of an agreement and acknowledge the sour relationship that existed at that time.

Having taken into consideration that the internal crisis requires a collaborative response, the Philippines turned to the US, but because of some unsettled grievances with the US, it later asserted a negative reception to the discussion of a new bases agreement. Nevertheless, these decisions made by the Philippines should not be initially seen as a submissive action on the part of the Philippines, but rather, a result of a keen observation and matured perspective of the Philippines on its security environment.

The Philippine-US relations, before and after its independence, had its own share of bumps on the road. Bumps that instigated a sensitive-adaptive method that took into consideration of the close assessment of the current relations. However, the rollercoaster 
ride seemed to have reached its end in 1991, that is, during the revolutionary government of President Cory Aquino (1986-1992). Due to the transitioning of the Philippines from authoritarian to democratic government, there was a call to create a new constitution. One of the provisions that was passed was the ban of US bases in the Philippines. ${ }^{1}$ This was by far, the most crucial decision made by the Philippines with regard to its relations with the US. However, it must be understood that such decision was against the backdrop of a heightened national patriotism amongst the Filipinos-due to the People Power-and the end of the Cold war. A heightened patriotism among the Filipinos shed light to the existence of US military presence in the Philippines and the end of the Cold War has made these bases lose its strategic focus and relevance to the security environment.

The termination of the bases, however, was not aimed to cut Philippine-US security relations entirely but rather, it called for a fresh security alliance that would be relative to the current security conditions present in both regional and global environments. Hence, in 1999, under President Joseph Estrada (19982001), the government restored American military presence in the country through a new form known as the Balikatan exercises or the RP-US Visiting Forces Agreement (VFA) ratified by the Senate on May 27, 1999 (Lim, 1987 , p. 15). The agreement aimed to establish the guidelines and provisions that covered the U.S. military personnel sent to the Philippines to conduct military exercises.

In the following years, the administration of President Gloria Macapagal Arroyo (2001-2010) and President Benigno Simeon Aquino III (2010-present) have been closely acquainted with a series of efforts that would further strengthen Philippine-US relations. Notable of these, were the "2001 bilateral defense consultative mechanism" 2

${ }^{1}$ This is a statement written by the Spokesperson of NDFP Mindanao Chapter, Ka Oris, "28 years hence, The EDSA promise is ever more elusive" on 25 February 2014. and the "2014 Enhanced Defense Cooperation Agreement" (Baviera 2014: 1). The common point of these mechanisms/agreements is a clear structure and increased number of rotational US Armed Forces in the Philippines. Again, there is a need to understand that the periods between 2001 and 2010-up to the present-is characterized with existing external threats-both regional and global. The global war on terror marked by the 9/11 attack instigated a reassessment of both the Philippines' and the US' foreign policies. Moreover, the growing dominance and aggressiveness of China with regard to its claim of South China Sea posed a security threat and a direct breach of the territorial sovereignty of the Philippines.

The constant interplay of factorsboth internal and external-plays a crucial role to the decisions made by the state. As for this case, there is sufficient evidence to support that there were a number of factors that affected the course of Philippine foreign policy toward the US. And so, it would not be fair to say that, the current Philippine-US Security relations is a show of a growing reliance and dependence of the Philippines to the US over its security concerns, primarily because such assumption shows no regard to the underlying intricacies of the Philippine-US relations. Hence, instead, this should be seen as a display of a strategic consideration of national interest at work and a point of maturity in the Philippines' independence.

\section{Economic Concerns}

In 1956, during the tenure of President Ramon Magsaysay (1953-1957), the 1955 LaurelLangley Agreement-a revised United StatesPhilippine Trade Agreement (or the Bell Trade Act), was negotiated (Rafaelita n.d., p. 5-9). This treaty had some advantages for the Philippines. It ended the US authority to control the exchange rate of the Peso. The bill

\footnotetext{
${ }^{2}$ See "Joint Statement between President George W. bush and President Gloria Macapagal-Arroyo of the Philippines on the $50^{\text {th }}$ Anniversary of the U.SPhilippine Alliance." Washington: Authenticated U.S. Government Information. 2001. 1699.
} 
also extended the sugar quota and the time period during which Philippine goods could be exported to the US without tariffs. These measures were concessions to the Philippine elite, in recognition of their commitment to the American cause. The agreement also contained provisions encouraging foreign investment in the Philippines, allowing increased American economic control. In particular, it granted foreign individuals and corporations the legal right to own land, which was opposed by many nationalists.

It was however, during President Carlos P. Garcia (1957-1961) that a radical shift in economic policy inadvertently happened. Seeing that the Philippine economy in the postwar period was dominated by American businesses, he wanted to steer the country away from a colonial dependence on export of raw materials and import of finished goods, and towards development of a modern industrial economy. In 1960, he asserted the need for Philippine economic freedom and promised to shake off "the yoke of alien domination in business, trade, commerce and industry." He pursued what became known as "Pilipino Muna" ("Filipino First"). The goal of this policy was to provide increased government support for the development of domestic industry (Pelorina, 2013, p. 25-26). This was well received by some sectors of the Filipino business community, but drew loud protests from American business circle. The US Government was not pleased because the policy hindered American business activity in the Philippines.

In response, the American-controlled World Bank and International Monetary Fund pressured Garcia to end import and currency restrictions. The US claimed that he tolerated graft and corruption in dollar allocations. There were rumors of a possible CIAsponsored coup against the government but many Filipinos were proud because President Garcia was the first Philippine President since independence in 1946 who stood up against the Americans. However under pressure, in December 1960 Garcia finally adopted partial fiscal decontrol; in other words, foreign businesses would be allowed to take their profits out of the country again. National elections were coming in 1961 and he knew he would need support from the American Government to win again.

Upon winning the 1961 elections, President Diosdado Macapagal (1961-1965)under pressure from the US Government and international financial institutions-reversed Garcia-era economic policies with economic liberalization policies. First, under Garcia's government, the Peso had a fixed exchange rate, to keep low prices for domesticallyproduced goods and food. However, Macapagal allowed the Peso to "float" on currency exchange markets, causing a nearly $100 \%$ devaluation of the Peso, leading to increased consumer prices, hurting Filipino consumers. Second, under Garcia's regime, foreign imports were limited in order to encourage domestic production by Philippine businesses. However, Macapagal lifted these limits, with the result that foreign imports flooded in, hurting domestic industries and agriculture, thus making the environment in the advantage of U.S businesses (Pelorina, 2013, p. 24).

The above mentioned is an attempt of the Philippines to deviate from the development path that the US envisioned. To a certain extent, the Philippines showed a sense of responsibility to finally decide on its own. The sudden shift was an attempt of the Philippines to prioritize its national interest over the dictate of the US as a manifestation of its independence from the US. However, the sudden spur of nationalism was not sustained as the Philippines still lacked institutional mechanisms to strengthen its own economy hence creating the imperative to consider the US assistance.

The rise of economic nationalism continued until the time of President Ferdinand Marcos (1965-1979). Responding to the global changes from bi-polar to multi-polar system, President Marcos devised an innovative approach to Philippine diplomacy which was called "New Development Diplomacy". It was designed to cater to the needs of economic and social development and reduce the excessive reliance of the Philippines to the US. The declaration of martial law in 1972 provided President Marcos the opportunity to direct Philippine foreign policy away from the Cold War orientation to his 
vision of Development Diplomacy. It is focused on the development of a national self-reliance which is based on economic progress and political stability. However, in 1980 s the Philippines was greatly affected by the oil price increases and the global recession. This led to trade deficit which was even exacerbated by the regime's growing internal weakness. As a result, Marcos found it necessary to maintain his diplomatic thrust toward the US. This was necessary because the US was the main supporter of the regime through its sale and grant of military hardware, its dominant role in the World Bank and International Monetary Fund, and by actions of US-based multinational corporations. As a consequence of his dependence to the US, President Marcos found himself vulnerable to American diplomatic pressures (Castro, 1989).

Series of events ultimately led to the downfall of Marcos and came the ascendancy into power by Corazon Aquino. The Philippines' debt strategy entails repayment of loans made during the Marcos period. This resulted to huge cash outflow that negated future economic growth much less recovery. The government's desperate need for new money to service the debt and finance economic recovery program forced the Philippine to compromise its independent posture. It compelled the Philippine to seek assistance from the US. Moreover the internal problem of the Philippine like insurgency, Muslim rebellion, the rightist threat and problems of economic development affected the country's ability to pursue an independent foreign policy since the government was far more concerned with its domestic problems; it depended on the US for economic assistance.

The succeeding regimes after the installation of democracy in the Philippines through Corazon Aquino's administration became more focused on propelling the country toward global competitiveness. This was initially evident during the time of President Fidel Ramos as there were intense diplomatic efforts exerted to encourage foreign investors to the Philippines. The country's economic growth became heavily dependent on foreign investments. Investors, however, were not solely coming from the US but from other countries. This showed that the
Philippines was starting to recognize other development partners apart from the US. Such economic development efforts were taken further during the time of President Gloria Macapagal Arroyo through bilateral and multilateral cooperation, between and among countries inside and outside the region. Moreover, the Philippines continued to pursue active regional strategy of participation in the ASEAN and the APEC, while steadily building up its bilateral alliance with the US (Abadilla, 2004, p. 36).

In the area of bilateral trade, relations have not only been growing, they also have been diversifying. Traditional Philippine exports to the US used to be dominated by sugar, coconut oil, and abaca. Today, the Philippines also exports higher-value goods such as electronics, computer chips, and garments. Moreover, the Philippines is already a major focus for overseas business processing operations (BPO) and call centers for growing list of US firms. Prospects are even brighter in the deepening integration of East Asian economies. Talks have progressed in promoting closer economic integration between the ASEAN region and the powerhouse economies of Northeast Asia (Abadilla 2004, p. 41). In short, the Philippines is gaining an economic foothold within its regional neighborhood, while at the same time maintaining its economic partnership with the US.

\section{The Philippines and the Bandung Spirit}

Although peoples of Asia and Africa do not have common cultural heritage and do not arise out of common civilization, there is however a single force that binds them together-the Bandung Spirit. It is a force that is characterized by collective abhorrence to colonialism, common desire for national political freedom, and shared vision of peaceful economic growth. It is the force which led the colonized countries to struggle for independence and emancipation.

Each nation, however, has its own interpretation and its own reading of the implications of the Bandung Spirit. The Philippines for that matter also had its own understanding of the symbolic significance of the Bandung Spirit. This section of the paper, 
therefore, discusses the Philippine understanding of the symbolic Bandung Conference. It argues that externally, the Bandung Conference exemplified a unified effort to quell colonialism and imperialism; internally, however, there seemed to be divergence among the participating countries on the implication of the Bandung Spirit. In light of this, the case of the Philippines as one of the participating countries in the Bandung Conference and a former colony of the US will be examined. This paper further argues that although the Philippines shared the common abhorrence to imperialism and exerted efforts to create its independent foreign policy, it was, to a certain extent, put under pressure by both domestic and international concerns that compelled it to engage with its former colonizer-the US. Such engagement, however, is not an irreverence of the Bandung Spirit but an adaptation of it.

Although this may send an impression on the ambiguity of the Philippines commitment to the Bandung Spirit-anticolonialism, political freedom and state-guided economic development-it should be perceived that such balancing act is a means by which the state adjusts or adapts to the evolving environment while preserving its national individuality.

The Philippines in the Bandung Conference In unity with the rest on the participating countries in the Bandung Conference, the Philippines shared the same sentiment against colonialism and imperialism and the quest for full national individuality. Carlos Romulo as the head of Philippine delegation in the Bandung Conference stated, "The US at times appeared to us lacking in consistency and vigor in upholding the right of non-self-governing peoples to independence. It has on some issues leaned heavily in favor of colonial power and has sometimes disheartened us in the Philippines because of its failure to make its actions dovetail with its ideals of equality and freedom."3 However, Romulo in his speech also

3 This is taken from Carlos Romulo's speech delivered during the Opening Session of the 1955 Bandung Conference in Indonesia. did not disregard the fact that the Philippines had also directly experienced the basic good faith of the US in the relationship. He further stressed, Let it be stated in fairness however that uniquely among the colonial powers the US in our case made a formal pledge of independence, fixed a date for it 10 years in advance and fully and honorably redeemed that pledge". Finally, he asserted, "We of Asia and Africa are emerging into this world as a new nation-states in an epoch when nationalism, as such, can solve only the least of our problems and leaves us powerless to meet the more serious one" (Romulo, 1956, p. 113). This implied that the Philippines perception of the Bandung Spirit was not a total absence or complete disregard of the importance of its former colonizer. Although it is one with the colonized countries in belief of their right to self-determination and full national individuality, the Philippines did not discount the fact that independence of the smaller or weak nation is at best a precarious and fragile thing.

Given the stand of the Philippines in the Bandung Conference, it was inevitable that Indian and the Philippine delegations found themselves on opposite sides of the fence: India was the leader of the neutralist states while the Philippines was among those in the forefront of the democratic alignment. This provided an impression that there was an internal divergence on some issues in the Bandung Conference. First is the issue of democratic alignment. The Philippines asserted that being democratic should not be equated to being pro-Western. The Philippines aligned itself to democratic ideals only because the ideals of freedom are universal.

Another divergence that manifested in the Bandung Conference was on the issue of peaceful coexistence within the region specifically on the issue of the Manila Pact. The Manila Pact, was signed on 8 September 1954 in Manila, as part of the American Truman Doctrine of creating anti-communist bilateral and collective defense treaties. These treaties 
and agreements were intended to create alliances that would contain communist powers. According to Nehru of India the Manila Pact is contrary to the spirit of agreements and understanding on nonaggression and non-interference. Moreover, it diminishes the "climate of peace" 4 in the region (Indonesian Ministry of Foreign Affairs, 1956, p. 65). However, Romulo asserted that he cannot see why the Manila Pact can be said to be inconsistent with non-interference and nonaggression. He argued that India, had it been a member of the Alliance, could expect no help under the alliance if it proposes to attack China or Pakistan or indeed any other state anywhere else in the world because the Manila Pact is a treaty of collective defense 5 and no aggressive purpose is written into it (Indonesian Ministry of Foreign Affairs, 1956, p. 70). The above discussion shows that externally, the Bandung Conference exemplified a unified effort to quell colonialism and imperialism; internally, however, there seemed to be divergence among the participating countries on the implication of the Bandung Spirit.

\section{The Bandung Spirit and the Philippine Foreign Policy}

At the core of the Bandung Spirit is the abhorrence to colonialism and imperialism and the right of colonized states to national individuality. However, in the course of the Philippines' formulation of its foreign policy it raises the question of whether the Philippines is living or leaving the Bandung Spirit as it still continues to have strong bilateral ties with its former colonial master-the US. This paper argues that the Philippines still lives in the spirit of the Bandung Conference. First, the balancing acts performed by the Philippines in crafting its foreign policies over the years were tactical in nature. The change in behavior of a state reflects recalculation of the most effective means to achieve its goals and to preserve and improve its relative capabilities. Interests do not change; only the means of pursuing interests change and strategies change because

4 Reply of General Romulo to Prime Minister Nehru of India before the Political Committee on 23 April 1955 . exogenous conditions change (Johnston, 1995, p. 35).

Looking at the history of Philippine foreign policy, it can be argued the balancing acts performed by the Philippines in the course of formulating its independent foreign policy was a recalculation of the most effective means to achieve its goal to improve its relative capabilities. For instance, on the issue of retaining the military influence of the US in the Philippines, the latter needed to maintain its cordial relationship with the US even after the decision of removing the US bases because it knew for a fact that it was inadequate to address domestic threats such as insurgency and international threats such as terrorism. Addressing such threats by recalculating its move against US enables the Philippines to strengthen its national security through burden-sharing but without over reliance to the US. In effect, what seemed to be a move away from the ideals of national individuality which is the very essence of the Bandung Spirit is actually a recalculation of the most effective means to improve its relative capabilities and ultimately attain national individuality.

The relationship between the Philippines and the US is no longer defined as colonizer-colony but instead a partnership between two equally sovereign states. Hence, it shows that the Philippines has the upper hand in determining its own development as a nation-state and no longer at the mercy of the US. The relationship that exists between the Philippines and the US is characterized by partnership of two equally sovereign states. The bilateral relations of the Philippine with the US side by side its active multilateral cooperation within the Southeast Asian region indicates that the Philippine is free to choose its economic strategy as a sign of full national individuality. In fact, the US and the Philippines are both key players of Asia-Pacific Economic Cooperation (APEC), which aims to achieve a Pacific Community of "free and open trade and investment" by 2020 (Abadilla, 2004, p. 39). Additionally, the Philippines has

5 Statement of Carlos Romulo, Chairman of the Philippine Delegation to the Asian African Conference on 23 April 1955. 
put emphasis on regionalism to lessen dependence on the US. Ever since the formation of ASEAN, the Philippines has perceived regionalism as a hedge against overdependence to the US. The Philippines has viewed regionalism as an instrument of pooling the region's technical and material resources so as to develop its economy which would strengthen its bargaining position and lessen its need for the US assistance and investments or any other special relations with the US (De Castro, 2010, p. 716-717). Hence, the relationship that exists between the Philippines and the US is no longer based on dominance but on partnership. As the Philippines defined its national individuality, the US, on the other hand, has also redefined its role relative to the national identity of Philippine in particular and in the regional identity of ASEAN in general.

Philippine-US Security Cooperation and China's Aggression in South China Sea

Although the US military bases have ceased to operate in the Philippines since 1992, two countries have maintained security cooperation. With China's growing assertiveness in the South China Sea, the US and the Philippine have discussed bolstering the US military presence in the Philippine, including allowing greater US ship and aircraft access to Philippine military facilities; increasing US military forces on a nonpermanent basis; and raising the number and frequency of joint military exercises, ship visits and related activities through the Enhanced Defense Cooperation Agreement (Lun, 2014, p. 20).

Since 2012, the Philippine has played a key role in the Obama Administration's "rebalancing" of foreign policy priorities to Asia, particularly as maritime territorial disputes between China and other claimants in the South China Sea intensified. However, the US does not take a position on the territorial dispute between the Philippine and China. The US is not a party to United Nations Convention on the Law of the Sea. It has no formal role in the case but the US officials have supported the Philippine's right to use available international arbitration mechanisms and argued that all parties should abide by the rulings of appropriate international legal institutions (Lun, 2014, p. 19).

Given Philippine constitutional prohibition and nationalistic sensitivities, there was no US bases or large scale troop alignment that have been proposed. The Philippine's need to increase its security in the face of China's aggression does not necessitate military dependence on the US. Instead, the Philippine opted to exhaust diplomatic means. The Philippine is the first to take China to the court. It decided to resort to compulsory arbitration despite China's vehement opposition. (Heydarian, 2015, p. 1). On the other hand, the US does not show desire to intervene in the domestic affairs of the Philippine. The US-Philippine Mutual Defense Treaty (MDT) of 1951, which forms the foundation of the bilateral security alliance, does not explicitly obligate the US to come to the defense of maritime areas that are disputed by the Philippine. During his April 2014 visit to the Philippine, President Obama asserted that the Treaty requires the US to help defend the Philippine against external armed attack, adding that "our commitment to defend the Philippine is iron-clad". However, he stopped short of saying that the MDT would apply to Philippine claimed islets in the South China Sea (Hachero, 2014, p. 1).

Amidst concern over the aggressive behavior of China over the disputed territory in South China Sea, the Philippine remains to display assertiveness of its territorial integrity through international legal institutions while maintaining security cooperation with the US. Hence, the Philippine maintains a delicate balance between assertiveness of its foreign policy and its security cooperation with the US.

\section{Conclusion}

The Bandung Conference was symbolic as it was the first major international conference that sought to bring together the governments of the newly independent nation of Asia and Africa. It was the first blueprint for solidarity between the colonized countries. The Philippines shared the common abhorrence to imperialism and exerted efforts to create its independent foreign policy. However, the Philippines, to a certain extent, was put under pressure by both domestic and international 
concerns that compelled it to engage with its former colonizer-the US. This necessitated the Philippines to perform a balancing act between its national interests and the US influence.

The creation of the Philippines independent foreign policy was a process characterized by the delicate balance between the Philippines national individuality and the US dominance. What seemed to be a move away from the ideals of national individuality is actually a recalculation of the most effective means to improve the Philippines relative capabilities and ultimately attain national individuality. The Philippines' engagement with the US, therefore, is not an irreverence of the Bandung Spirit but an adaptation of it.

The Philippines remains to live up to the ideals of the Bandung Conference as it displays the abhorrence to imperialism, commitment to political freedom and peaceful economic growth within its neighborhood-all of which are at the core of the Bandung Spirit. The Bandung Spirit, therefore, still lives albeit redefined to fit in to the evolving security environment.

\section{Bibliography \\ Books}

Abdulgani, H. R. (1964) Bandung Spirit. Jakarta: Badan Penerbit Prapantja.

Acharya, A. (2008) The Evolution of Norms: The Social Construction of NonInterference in Asian Regionalism. Paper for the Provincializing Westphalia Conference. Oxford University.

Baker, C. (2005) Philippines and the United States 2004-2005: Defining Maturity. Hawaii: Asia Pacific Center for Security Studies.

Berger, M. T. (2008) The Battle for Asia: From Decolonization to Globalization. New York: Routledge Curzon.

Cooley, A. (2008) Base Politics: Democratic Change and the U.S. Military Overseas. New York: Cornell University Press.

Indonesian Ministry of Foreign Affairs. AsiaAfrica Speaks From Bandung. Jakarta: The Ministry of Foreign Affairs, Republic of Indonesia, (n.d.).
Jayman, J. (2001) Towards Consensus after Bandung: Global Public Goods and Mitigating Uneven Development. New York: St. Lawrence University.

Mercado-Aldaba, R. A. (1994) Foreign Direct Investment in the Philippines: A Reassessment. Philippine: Institute for Development Studies.

Overholt, W. H. (1986) The Rise and Fall of Ferdinand Marcos. Los Angeles: University of California Press.

Romulo, C. P. (1956) The Meaning of Bandung. North Carolina: University of North Carolina Press.

Stephens, W. D. (1990) The Roots of Social Protest in the Philippines and Their Effects on U.S.-R.P. Relations. California: Naval Post-Graduate School.

Tan, S. S. and Amitav A. (2008) Bandung Revisited: The Legacy of the 1955 Asian-African Conference for International Order. Singapore: NUS Press.

\section{Journals}

Abadilla, A. (2004) RP-US Patternship for Peace and Development. Philippine Diplomacy in the 21st Century. Makati City: Hanns Seidel Foundation.

Baviera, A. S. P. (2014) Implications of the U.SPhilippines Enhanced Defense Cooperation Agreement. Asia Pacific Bulletin. Washington D.C.: East-West Center.

De Castro, R. C. (2010) Weakness and Gambits in Philippine Foreign Policy in the Twenty-first Century. Pacific Affairs 83.4, p. 697-717.

Castro, R. de. (2002) Historical Review of the Concept, issues and Proposals on an Independent Foreign Policy for the Philippines: 1955-1988. Asian Studies 27, p. 7-34.

Chin, L. (2002) The United States in the Philippines: Post 9/11 Imperatives. Center for Research on GlobalizationOnline Journal.

Johnston, A. I. (1995) Thinking about Strategic Culture. International Security, 19.4, p. 32-64. 
Pelorina, R. N. (n.d.). (2013) Decontrol and Its Effects on Philippine Economy (19621966). Journal of Arts, Science, and Commerce 4.1, p. 23-35.

Technology Integration Division. (2011) Philippines In Perspective: Orientation Date. Defense Language Institute Foreign Language Center.

Ross, R. (2013) US Grand Strategy, The Rise of China, and US National Security Strategy for East Asia. Strategic Studies Quarterly.

\section{Newspaper Articles}

Hachero, A. (2014) DFA Insists US Will Help PH If Attacked. Malaya.

\section{Online Articles}

Communist Party of the Philippines. (2011) Resist Plan to Allow US to Re-establish Military Presence in Subic -eCPP. [Online]. Philippine Revolution. Available from: <http://www.philippinerevolution.ne t/statements/20110428_resist-planto-allow-us-to-re-establish-militarypresence-in-subic-cpp>.

Heydarian, R. J. (2015) China vs. the Philippines: Will International Law Resolve South China Sea Disputes? [Online]. The Huffington Post. Available from: < http://www.huffingtonpost.com/rich ard-javad-heydarian/china-vs-thephilippines-_b_7766406.html>

Independence Day in Philippines. [Online]. Time and Date AS. Available from: <http://www.timeanddate.com/holid ays/philippines/independence-day $>$.

Lim, M. T. M. (1987) Removal Provisions of the Philippine-United States Military Bases Agreement: Can the United State Take it All. [Online]. Loyola Law Review Los Angeles. Available from: $<$ http://

http://digitalcommons.lmu.edu/llr/v ol20/iss2/5/>.

Lum, T. (2012) The Republic of the Philippines and U.S. Interests. [Online]. CRS Report for Congress. Available from: < https://fas.org/sgp/crs/row/RL3323 3.pdf $>$.
Lum, T. and Ben D. (2014) The Republic of the Philippines and the US Interests 2014. [Online]. Congressional Research Service. Available from: <http://www.fas.org/sgp/crs/row/R4 3498.pdf $>$.

Malaya, J. E. (2011) Constitutional Processes Requirement in the PH-US Mutual Defense Treaty. [Online]. Philippine Law Journal Online. Available from: <http://plj.upd.edu.ph/wpcontent/uploads/plj/PLJ\%20volume \%2085/PLJ\%20volume\%2085\%20\% 20issue\%204/layout11-issue4.pdf $>$.

Resos, A. B. (2013) International Realities and Philippine Foreign Policy under Ferdinand Marcos. [Online]. Foreign Policy Journal. Available from: <http://www.foreignpolicyjournal.co $\mathrm{m} / 2013 / 10 / 28 /$ internationalrealities-and-philippine-foreignpolicy-under-ferdinand-marcos/>

Rosario, A. F. (2012) A Principled Philippine Foreign Policy. [Online]. The Philippine Embassy in London, United Kingdom. Available from: <http://philembassy-uk.org/aprincipled-philippine-foreign-policyby-secretary-albert-f-del-rosario $>$.

Shalom, S. R. "Securing the U.S-Philippine Military bases Agreement of 1947. [Online]. Bangladesh Centre for Advanced Studies. Available from: <http://www.wpunj.edu/dotAsset/20 9673.pdf $>$.

Shalom, S. R. Why and How Parity Rights/Military Bases Agreements Got Approved -Selfish and Traitorous Betrayal by Our Native Rulers (Part 1 of 2). [Online]. The Filipino Mind. Available from: <http://www.thefilipinomind.com/2 012/11/how-us-philippine-militarybases.html>.

\section{Thesis}

Sugai, C. M. (2009) U.S.-Philippine Security Relations after Base Closure (19911999). MADMS Thesis. Hawai'i Pacific University 